\title{
Four years, and 12 issues later
}

\section{K. Brad Wray ${ }^{1} \cdot$ Luciano Boschiero $^{2}$}

Published online: 21 September 2018

(C) Springer Nature B.V. 2018

This is the final issue in our fourth year as editors. It is truly unbelievable to us that so much time has passed since Stathis and Theodore handed over the editorship of the journal to us. We have now hit our stride, and despite the many distractions between each issue of the journal, we have managed to settle on a set of practices that ensure that we have each new issue ready on schedule. No doubt we continue to rely heavily on and benefit from our many supports, our assistant editor, Lori Nash, our production contact in the Netherlands, Eric Pieren, Lucy Fleet, of course, and the many other people who help us get each issue out in time.

Every issue is different, in some way or other. This issue includes three book symposia. There are thoughtful, engaging author-and-critics exchanges on the following three recently published books: Anjan Chakravartty's Scientific Ontology: Integrating Naturalized Metaphysics and Voluntarist Epistemology, Evelleen Richards' Darwin and the Making of Sexual Selection, and Michael Esfeld's and Dirk-André Deckert's A Minimal Ontology of the Natural World. These symposia attest to the vibrancy of our fields. Each symposia is a spirited exchange between astute critics and the book authors. We congratulate each of the book authors for what, according to their peers, are great contributions to the scholarly literature.

This issue of the journal also includes, as usual, a variety of book notes, book reviews, and essay reviews on a range of topics in history and philosophy of science, and science studies. We thank all our reviewers for their part in this successful endeavour. We would also like to remind authors of recent books to be sure to contact us either directly, or through their publishers, to alert us to the publication of their news books. The journal is committed to providing a comprehensive review of new books in the history of science, the philosophy of science, and science studies.

\footnotetext{
K. Brad Wray

kbwray@css.au.dk

Luciano Boschiero

1.boschiero@campion.edu.au

1 Aarhus University, Aarhus, Denmark

2 Campion College, Sydney, Australia
} 